Ким А. В.
О МЕРАХ ГОСУДАРСТВЕННОЙ ПОДДЕРХКИ РЕЗИДЕНТОВТЕРРИТОРИИ ОПЕРЕХАЮЩЕГО СОЦИАЛЬНО-ЭКОНОМИЧЕСКОГО РАЗВИТИЯ (НА ПРИМЕРЕ ДАЛЬНЕГО ВОСТОКА)

Kim A. V.

\title{
ON MEASURES OF STATE SUPPORT TO RESIDENTS OF THE TERRITORY OF PRIORITY SOCIAL AND ECONOMIC DEVELOPMENT (BY THE EXAMPLE OF THE FAR EAST)
}

В статье проанализированы преференции для резидентовтерриторий опережающего социально-экономического развития, обозначены преимущества специального режима для представителей бизнеса. Раскрыты практические проблемы и предложены пути их решения.

Ключевые слова: бизнес, земельные участки, меры поддержки, резиденты, преференции, финансовые льготы.

The article analyzes the preferences for residents of territories of advanced social and economic development, outlines the advantages of a special regime for business representatives. Practical problems are disclosed and ways to solve them are proposed.

Keywords: business, land, support measures, residents, preferences, financial benefits.

С вступлением в силу федерального закона от 29 декабря 2014 г. № 473-Ф3 «О территориях опережающего социальноэкономического развития в Российской Федерации»в регионах Дальнего Востокасоздано 20 территорий с названным статусом.Функциональное назначение территории опережающего социальноэкономического развития (далее - ТОР) заключается в установленииспециального правовой режима для осуществления коммерческой деятельности. Создание благоприятных условий с целью привлечения инвестиций, обеспечения ускоренного социально-экономического развития, комфортная среда для обеспечения жизненно необходимых потребностей населения являются основной целью государственной политики в этом направлении.

Президентом России было поручено Правительству Российской Федерации провести серьезную работу по совершенствованию законодательства РФ и обеспечить внесение изменений, предусматривающих гарантию стабильности пра- вовых и налоговых условий осуществления деятельности для резидентов ТОР и резидентов свободного порта Владивосток в течение 10 лет со дня получения ими соответствующего статуса (под. «а» п. 1 поручения Президента России по итогам рабочей поездки в Дальневосточный федеральный округ 5-8 сентября 2017 года №Пр-1968 от 27 сентября 2017 года, пункт 3)[4].

Для представителей бизнеса - резидентов ТОР ведущих экономическую деятельность на законодательном уровне гарантирован комплекс административных, финансовых, таможенных, имущественных и иных преференций.

В качестве примера можно рассмотреть возможность получения земельного участка в границах ТОР по договору аренды, на котором планируется реализация бизнес-проекта. В отличии от стандартного заявительного порядка резидентам ТОР предоставляется земельный участок без проведения торгов в пределах кадастровой стоимости. Информация о наличии земельных участков и недвижи-
23 
мого имущества размещается на официальном сайте управляющей компании. Обязательным условием является обозначение координат земельного участка в дополнительных сведенияхк заявке на заключение соглашения с управляющей компанией об осуществлении деятельности на территории опережающего социально-экономического развития.

Несмотря на имеющийся упрощенный порядок получения земельного участка на практике у некоторых резидентов ТОР Дальнего Востокавозникают проблемы в осуществлении на нем хозяйственной деятельности, поскольку он находится в границах «запретной зоны». Сложность заключается в том, что в настоящее время нормативно не определен порядок вывода таких земель, поэтому резиденты вынуждены обращаться за помощью в органы власти. При таких обстоятельствах имеет место несение убытков, связанных с арендной платой, а также иных расходов еще до начала ведения коммерческой деятельности[6].

Помимо этого, невзирая на законодательные предписания в части передачи управляющей компании на праве собственности или аренды земельные участки, здания, строения, сооружения, находящиеся в государственной или муниципальной собственности и расположенныхв границах ТОР на деле, возникают спорные ситуации.В некоторых случаях региональные и муниципальные органы отстаивают свои интересы в вопросах передачи земель и имущества. Подобные разногласия разрешаются в судебном порядке, что затягивает процедуру полученияземли и тормозит развитие бизнеса [1].

K административным преимуществам можно также отнести существенное сокращение сроков на некоторые административные действия со стороны органов власти разного уровня. Так, например, при планировании строительства в границах ТОР подготовка разрешительной документацией на объекты капитального строительства и прохождение процедуры по согласованию с органами власти осуществляетсярезидентами при поддержке Минвостокразвития России.

Предоставление финансовых льгот является одной из значимых мер государственной поддержки резидентов ТОР. В течении 10 лет размер страховых взносов составляет 7,6 \% в отличии от иных субъектов бизнеса, для которых предусмотрен 30 \% размер аналогичных взносов. Налоговые преференции также отличаются полным освобождением резидентов от уплаты налогов на прибыль, на имуще- ство и на землю в течение 5 лет. Однако, льготы на страховые взносы не распространяются на резидентов ТОР, которые приобрели статус до 26 июня 2018 года, поскольку названные льготы были установлены положениями Федерального закона от 03.08.2018 № 300-ФЗ «О внесении изменений в статью 5 части первой и статьи 422 и 427 части второй Налогового кодекса Российской Федерации» [2]. Это означает, что большая часть резидентов TOP не может воспользоваться финансовой преференцией по страховым взносам.

По случаю внесения изменений в Налоговый кодекс РФ Федеральная налоговая служба России (далее - ФНС РФ) в письме от 28.05.2019 № БС-4- 11/10247@ опубликовала официальные разъяснения по вопросу применения пониженных тарифов страховых взносов резидентами территорий опережающего социальноэкономического развития и резидентами свободного порта Владивосток[5]. Из письма следует, что применять пониженные тарифы страховых взносов возможноисключительно в отношении выплат, начисляемых работающим только по трудовым договорам физическим лицам, занятым на новых рабочих местах, созданных для исполнения соглашения об осуществлении деятельности. Это означает, что значительная часть резидентов ТОР не может воспользоваться финансовой преференцией по страховым взносам.

На региональном уровне законодательными актами, регулирующими вопросы налогообложения, принимаются нормы, предусматривающие преференции для резидентов ТОР. Так, в Хабаровском крае законом от 10 ноября 2005 г. № 308 «О региональных налогах и налоговых льготах в Хабаровском крае» предусмотрена ставка в размере 0 \% в течение пяти налоговых периодов для организаций, получивших статус резидентов ТОР. Вместе с тем законодателем оговорены условия применения такой льготы (часть 7 статьи 2). В частности, речь идет об имуществе, которое создано (приобретено) в рамках реализации бизнес-плана, прилагаемого к заявке на заключение соглашения об осуществлении деятельности в границах ТОР. Обязательным требованием является то, что названное имущество должно быть принято на учет в качестве объектов основных средств после дня включения организации в реестр резидентов территории опережающего социально-экономического развития и не было ранее использовано как объект другими лицами, и располагаться на терри- 
тории опережающего социально-экономического развития[3].

Примечательно, что представители бизнес, проявившие интерес к статусу резидента ТОР, как правила, уже занимаются предпринимательской деятельностью, следовательно, имеют на балансе имущество. Недостатками таких условий является то, что на имущество, не указанное в заявке, но приобретенное в процессе хозяйственной деятельности резидента ТОР региональная налоговая льгота не распространяется. Фактически это означает, что на практике создается парадоксальная ситуация.

Преференциальным режимом могут воспользоваться далеко не все резиденты TOP, а лишь те, кто подходит под установленные законодательные критерии.Обозначенные проблема весьма актуальны для действующих резидентов ТОР, поэтому для ее решениянеобходимо внесение изменений в Налоговый кодекс РФ. Это позволитустранить ограничения по распространению преференций на резидентов ТОР, заключивших соглашение с управляющей компанией об осуществлении деятельности и включенных в реестр с момента получения статуса резидента ТОР.

С целью совершенствования положений закона Хабаровского края от 10 ноября 2005 г. № 308 «О региональных налогах и налоговых льготах в Хабаровском крае» и улучшении налогового режима для резидентов ТОР было бы полезно исключить условия, ограничивающие права резидентов ТОР в части обязательных требований к имуществу организаций, занимающихся хозяйственной деятельностью.

\section{Литература}

1. Собрание законодательства РФ. 2015.№ 1 (часть І).Ст. 26.

2. Собрание законодательства РФ. 2018. № 32 (часты). Ст. 5093.

3. Собрание законодательства Хабаровского края. 2005 № 11 (40).

4. Сайт Правительства Российской Федерации / Режим доступа : /http:// government.ru/docs/ (Дата обращения: 02.02.2020).

5. Сайт Федеральной налоговой службы РФ / Режим доступа : / https://www. nalog.ru/rn27/ (Дата обращения: 02.02.2020).

6. Доклад Самусенко Е.А. Свободный порт Владивосток и опережающего социально-экономического развития территории: возможности и риски // VTихоокеанский юридический форму: «Роль права в развитии интеграционных процессов в Азиатско-Тихоокеанском регионе: современные тенденции и вызовы.

\section{References}

1. Sobraniye zakonodatel'stva RF. 2015.№ 1 (chast' I).St. 26.

2. Sobraniye zakonodatel'stva RF. 2018. № 32 (chast'I). St. 5093.

3. Sobraniye zakonodatel'stva Khabarovskogo kraya. 2005 № 11 (40).

4. Sayt Pravitel'stva Rossiyskoy Federatsii / Rezhim dostupa : /http://government. ru/docs/ (Data obrashcheniya: 02.02.2020).

5. Sayt Federal'noy nalogovoy sluzhby RF / Rezhim dostupa : / https://www.nalog. ru/rn27/ (Data obrashcheniya: 02.02.2020).

6. Doklad Samusenko Ye.A. Svobodnyy port Vladivostok i operezhayushchego sotsial'no-ekonomicheskogo razvitiya territorii: vozmozhnosti i riski // VTikhookeanskiy yuridicheskiy formu: «Rol' prava v razvitii integratsionnykh protsessov v Aziatsko-Tikhookeanskom regione: sovremennyye tendentsii i vyzovy.

Ким Александра Владимировна, кандидат юридических наук, доцент кафедры государственно-правовых дисциплин юридического института Тихоокеанского государственного университета. 680035, Россия, г. Хабаровск, ул. Тихоокеанская, 136. E-mail: Aleksandrina1985@inbox.ru.

Kim Alexandra Vladimirovna, candidate of legal sciences, associate professor of state and legal disciplines of law department of the Pacific state university. 680035, Russia, Khabarovsk, st. Pacific, 136.

E-mail: Aleksandrina1985@inbox.ru. 